\section{Altered state of corporal consciousness related to alien hand syndrome and schizophrenic motor passivity}

\author{
Estado alterado da consciência corporal \\ associado ao fenômeno da mão estrangeira \\ e passividade motora esquizofrênica
}

\section{Dear Editor}

Alien hand syndrome, a neglected phenomenon in Psychiatry, is one of the most intriguing examples of altered auto-perception in brain injury cases. The main feature of alien limb phenomenon is the individual's perception of the affected hand as being out of volitional control while performing simple to complex extravolitional motor activities. ${ }^{1,2}$

We report here the case of a 41 years-old, left-handed, HIV positive, white woman who was admitted at our university hospital presenting, during the previous month, right hemicranial headache, associated with fever, shivers, vomiting and asthenia. She also complained about a pulling sensation at her mouth on the left side, as well as local erythema and drooling. At the same period, she developed brief episodes of left hand weakness, associated with dysarthria. Two weeks later, the patient lost control of her left hand, mainly at night: when she woke up, her left hand was grasping her right arm. Since then, her dominant hand has presented extravolitional movements, as having a will of its own, not responding to volitional commands such as opening a door or catching an umbrella, but grasping objects that were useless for the patient at the moment, and wich she could not easily release. For many times, the patient realized that her left hand was in front of her face, as if it were 'looking' at her. She was afraid of her hand: "it seemed to be a monster". It also scratched and hurt the patient's face and body. She had been talking to her hand and even fighting with it.

Alien limb sign represents not only the failure in perception of the body as a whole (reminding a body scheme deficit), but also a dissociative-like phenomenon in which the alien limb assumes its own "personality" as if it had an independent life.

Self-recognition and self-awareness impairment has been traditionally associated with the right brain hemisphere, ${ }^{3,4}$ which appears to be dominant in somaesthesis, stereognosis, and the maintenance of the body image. It also appears that the right hemisphere can independently act without the aid or active reflective participation of the left one, thus leading to situations in which the right and left halves of the brain sometimes act uncooperatively, causing inter-manual and intra-psychic conflicts, ${ }^{4}$ such as that observed in alien limb phenomenon.

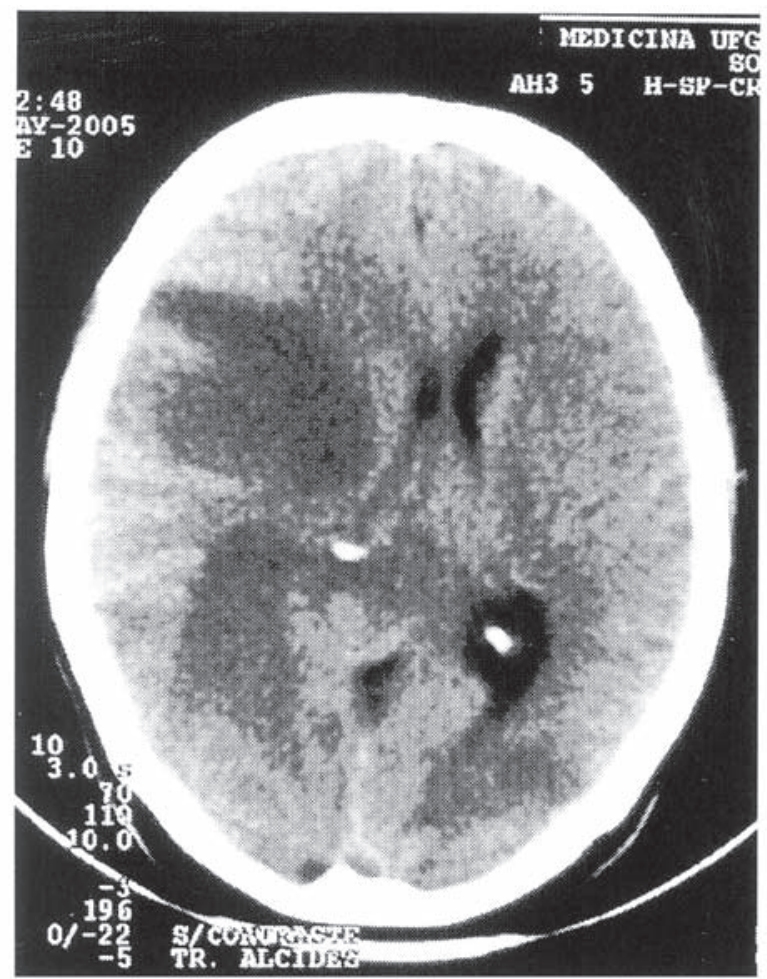

Figure 1 - CT showing right frontal and parietal hypodensity

Some patients with schizophrenia present a related phenomenon in which they believe their limbs are under the control of an alien force (motor passivity). ${ }^{5}$ There are some attempts to elucidate the nature and mechanism of passivity phenomena (experiences that one's conscious actions or thoughts have not been 'willed' by oneself) wich include the dysfunction of an internal self-monitoring system that normally enables the distinction between internally generated actions and external influences on intentional behavior. Motor imagery is the mental simulation of specific motor actions and it is based upon the internal representation of intended but unexecuted motor actions. ${ }^{5}$

We propose, therefore, that alien limb phenomenon can represent a very bizarre kind of altered state of body consciousness related to a right hemisphere disturbance and that they share symptomatological characteristics and possible pathogenic grounds with the schizophrenic motor passivity.

Leonardo Caixeta Hospitas das Clínicas, Universidade Federal de Goiás (UFG), Goiânia (GO), Brazil

\title{
Disclosures
}

\begin{tabular}{|c|c|c|c|c|c|c|c|}
\hline $\begin{array}{c}\text { Writting group } \\
\text { member }\end{array}$ & Employment & $\begin{array}{l}\text { Research } \\
\text { grant }^{1}\end{array}$ & $\begin{array}{c}\text { Other research grant or } \\
\text { medical continuous education }\end{array}$ & $\begin{array}{l}\text { Spekear's } \\
\text { honoraria }\end{array}$ & $\begin{array}{l}\text { Ownership } \\
\text { interest }\end{array}$ & $\begin{array}{c}\text { Consultant/ } \\
\text { Advisory board }\end{array}$ & Other $^{3}$ \\
\hline Leonardo Caixeta & UFG & -- & -- & -- & -- & -- & -- \\
\hline
\end{tabular}

\section{* Modest}

** Significant

*** Significant. Amounts given to the author's institution or to a colleague for research in which the author has participation, not directly to the author.

Note: UFG = Universidade Federal de Goiás

For more information, see Instructions to authors. 


\section{References}

1. Szirmai I, Kamondi A. Consciousness and altered consciousness. Ideggyogy Sz. 2006;59(1-2):17-28.

2. Hanna PA, Doody RS. Alien lim sign. Adv Neurol. 2000;82:135-45.

3. Keenan JP, Rubio J, Racioppi C, Johnson A, Barnacz A. The right hemisphere and the dark side of consciousness. Cortex. 2005;41(5):695-704.

4. Joseph R. The right cerebral hemisphere: emotion, music, visualspatial skills, body-image, dreams, and awareness. J Clin Psychol. 1988;44(5):630-73.

5. Maruff P, Wilson P, Currie J. Abnormalities of motor imagery associated with somatic passivity phenomena in schizophrenia. Schizophr Res. 2003;60(2-3):229-38. 